\title{
The introduction of oxygen for pneumonia as seen through the writings of two McGill University professors, William Osler and Jonathan Meakins
}

\author{
C Peter W Warren MA MB FRCPC
}

\begin{abstract}
CPW Warren. The introduction of oxygen for pneumonia as seen through the writings of two McGill University professors, William Osler and Jonathan Meakins. Can Respir J 2005;12(2):81-85.

Oxygen was identified at the end of the 18th century by three independent researchers. It was first used indiscriminately with other gases for treatment of pulmonary diseases by Thomas Beddoes. In the 19th century, the physiological properties of oxygen were identified by many researchers. In that same century, physicians used oxygen empirically for a variety of conditions. Osler, who wrote on pneumonia, appreciated that blood was "imperfectly oxidised" (sic) in pneumonia, but concluded that the toxicity of oxygen more than outweighed its possible benefits. Meakins applied the lessons he learned from studying the hypoxemia that resulted from poison gas in World War I to pneumonia. He confirmed that patients with severe pneumonia were hypoxemic and that many of their symptoms appeared to be relieved by inhalation of oxygen. Oxygen then became the standard therapy for pneumonia.
\end{abstract}

Key Words: History; Oxygen; Pneumonia

The purpose of the present paper is to look at the introduc1 tion of oxygen treatment for pneumonia through the writings of two Canadians, Sir William Osler and Jonathan Meakins, both professors at McGill University (Montreal, Quebec). The present paper focuses on the use of oxygen in pneumonia because, as Osler wrote, "Pneumonia is one of the most widespread of acute diseases. Pneumonia is one of the most fatal of acute diseases. Hospital statistics show that the mortality is from twenty to forty percent" (1). I believe that the reader will be helped to appreciate the viewpoint of these two physicians if I provide a summary of the knowledge available to them by summarizing the medical history of oxygen. These publications will guide the reader to the original references, although I fear scholars who wish to read them may have to visit such great institutions as the Wellcome library (London, United Kindom) to satisfy their curiosity.

\section{BACKGROUND}

The 17 th century

The 17th century saw the first observations that combustion in air was linked to respiration, and that exposure to air could
L'introduction de l'oxygène dans le traitement de la pneumonie à travers les écrits de deux professeurs de l'université McGill, William Osler et Jonathan Meakins

C'est à la fin du XVIII e siècle que trois chercheurs indépendants ont identifié l'oxygène. Il a d'abord été utilisé sans discrimination avec d'autres gaz pour le traitement des maladies pulmonaires par Thomas Beddos. Au $\mathrm{XIX}^{\mathrm{e}}$ siècle, les propriétés physiologiques de l'oxygène ont été reconnues par de nombreux chercheurs. C'est dans ce siècle également que les médecins ont utilisé l'oxygène de façon empirique pour diverses maladies. Osler, qui a écrit sur la pneumonie, disait que le sang était « oxydé de façon imparfaite " (imperfectly oxydised) en présence de pneumonie, mais concluait que la toxicité de l'oxygène surclassait ses avantages possibles. Meakins a appliqué à la pneumonie les leçons qu'il avait apprises lors de ses travaux sur l'hypoxémie résultant de l'empoisonnement au gaz durant la première guerre mondiale. Il a confirmé que les patients atteints de pneumonie sévère présentaient une hypoxémie et que bon nombre de leurs symptômes semblaient soulagés par l'inhalation d'oxygène. L'oxygène est alors devenu la norme thérapeutique en cas de pneumonie.

change the colour of the blood. The dominant work in this field was performed in Padua (Italy) and then, through the influence of its star pupil, William Harvey, at Oxford University (Oxford, England) (2). Much was learned through the experiments of Columbo and Fracassati at Padua, and Boyle, Willis, Hooke, Lower and Mayow at Oxford (2). Their experiments were guided by their understanding of the body based on theories of the humors and the Galenic vital spirit. Their observations gave rise to doubts about the dogma they had inherited; for instance, that the dark blood at the bottom of standing blood was the black humour. Mayow demonstrated that a burning candle and a live mouse consumed air, and concluded that the "loss of elasticity" of the air was due to the consumption of nitroaerial particles (2). The role of oxygen was yet to come, and none of this basic science was applied to clinical medicine.

The 18th century

Physiology: Oxygen was first identified in Sweden by Scheele in 1772, who called it fire air; he communicated his discovery in a letter to Lavoisier in Paris (France), but this description

History of Medicine Program, University of Manitoba, Winnipeg, Manitoba

Correspondence and reprints: Dr Peter Warren, RS 115-HSC, 810 Sherbrook Street, Winnipeg, Manitoba R3A 1R8. Telephone 204-787-2338, fax 204-787-2420,e-mail warrencp@ms.umanitoba.ca 
was suppressed for two centuries and Scheele's full publication came later (3). Independently in England, Priestley discovered the gas in 1774; he is traditionally credited with the discovery because he publicly presented his work before others (3). Lavoisier named it oxygen and studied many of its properties, which led to his refutation of the phlogiston theory of combustion; shabbily, Lavoisier did not give due honour to the other researchers (3). However, if Lavoisier's claim for primacy is to be supported, it is an illustration of Osler's aphorism: "In science the credit goes to the man who convinces the world, not to the man to whom the idea first occurs" (4). Priestley (5) conjectured "that it might be peculiarly salutary to the lungs in certain morbid cases" but he also inferred from his experiments,

"that though pure dephlogisticated air might be very useful as a medicine, it might not be so proper for use in the usual healthy state of the body...A moralist, at least, may say that the air which nature has provided for us is as good as we deserve."

Therapeutics: Thomas Beddoes (1760-1808) became the leading authority on the use of gases for treatment in medicine a branch of therapeutics known as pneumatic medicine. Beddoes, who had been lecturer of Chemistry at Oxford, had translated Lavoisier's work and was a friend of Priestley's son. Beddoes set out to treat diseases, particularly tuberculosis, with gases and founded the Pneumatic Institute in Bristol, England (6). He administered a number of gases including carbon dioxide and monoxide, hydrogen, chlorine, nitrous oxide and oxygen. Beddoes was influenced by the Brunonian concept of inflammation in tuberculosis and saw oxygen as a stimulant to counteract the asthenic form present (7). Beddoes described the pleasure of breathing oxygen with which he experienced "that agreeable glow and lightness of the chest, which had been described by Dr. Priestley and others", and in due course, "I perceived a carnation tint at the end of the fingers" (8). Beddoes was overweight, and developed respiratory problems, dying at 48 years of age (6). Therefore, he may well have been hypoxemic, although he described his natural hue as brown, not blue. Most tellingly, Beddoes mentored the medical student Humphry Davy whom he appointed director of his Pneumatic Institute. Davy, at the threshold of his renowned scientific career, studied the properties of gases, especially nitrous oxide (9). Aided by the inventor James Watt, he used a spirometer to collect gases and measure lung volume. Davy showed that both oxygen and carbon dioxide were present in the blood. He performed animal experiments, and although he noted "animals have always appeared to suffer extremely, soon after immersion in unmixed oxygene air" (9), he found that other gases, such as carbon dioxide and hydrogen, were more lethal to animals. Davy found that he could rebreathe oxygen longer than the other gases. The oxygen, approximately $85 \%$ pure, was prepared by heating oxides of manganese (9). Davy thought that oxygen eased all types of breathlessness, but it failed to cure consumption. Beddoes realized that his pneumatic medicine was ineffective and the institute closed.

\section{The 19th century}

Physiology: Oxygen drew the attention of 19th century physiologists (10). They confirmed that the blood takes oxygen into the lungs, although it was debated as to whether this occurred through diffusion or secretion. Oxygen was shown to form a loose association with hemoglobin. This acquisition changed the colour of the blood from purple to scarlet - the carnation tint of Beddoes. Bert, challenged by the hazards of ballooning and caisson disease, studied the relationship of oxygen pressure to oxygenation, and his experiments revealed the hazards of excessive oxygen, such as convulsions (11).

Therapeutics: In the 19th century, oxygen was given for various complaints as revealed by a browse through English language papers listed under oxygen treatment in the index catalogue of the Library of the Surgeon General's Office and Index Medicus. Case reports and benefits of oxygen in observational papers are found quite frequently in such journals as the Lancet, British Medical Journal and Journal of the American Medical Association. Today, such case reports are viewed as anecdotal and of the empirical type. To give the reader a flavour of these case reports, I have chosen two papers because the author's name is well-known. In 1888, Dr JH Kellogg, brother of the famous cereal proprietor, recommended oxygen enemas as a cure for liver disorders (12). With modern eyes, we might call such an endeavour quackery. However, this paper is of interest to our topic because Dr Kellogg wrote, "The wonderful vitalizing and invigorating influence of oxygen is unequalled by any other agent in nature" (12). Interestingly, Kellogg wrote that he used oxygen for pneumonia and emphysema, but thought it too expensive to be practical; to raise the inspired oxygen by $1 \%$ for a day needed 22 cubic feet at a cost of US\$2 and US\$6 for the equipment. Empirical therapy is exemplified by the case report of the renowned cardiologist Lauder Brunton, who described the temporary benefit of the now commercially available oxygen to a clergyman dying of pneumonia; with oxygen, he improved temporarily, although one can speculate that the medical strychnine administered may have contributed to his demise (13).

\section{The writings of William Osler}

The previous information is the background to Osler's knowledge of oxygen. His first mention of oxygen for pneumonia was during his lecture on pneumonia that was part of the summer session at McGill University in 1882 (14). His focus in the lecture was the pathology of pneumonia, a reflection on that period of his career. Referring to the symptoms of pneumonia, he stated that because of the fever, there is an increased need for oxygen and, hence, respiration is increased in number. $\mathrm{He}$ described the high respiratory rate in four cases but did not mention the cyanosis one might have expected. Osler first referred to treating with oxygen in an 1887 editorial: "the inhalation of oxygen as recommended by Dr Loomis in edema has an important use whenever, as shown by the lividity, the blood is imperfectly oxidized (sic)" (15). This was the only mention of oxygen in his papers.

In 1892, Osler published his influential textbook The Principles and Practice of Medicine (1). By its 6th edition in 1905, it had sold over 100,000 copies. From the beginning, it was the recommended textbook at many medical schools. The book is also credited with inspiring the funding of medical research by the Rockefeller Foundation (16). In its first two editions, Osler did not mention oxygen for treatment of pneumonia. But in the 
third edition in 1898 (17), his opening comments are discouraging:

"Oxygen Gas. It is doubtful whether the inhalation of oxygen in pneumonia is really beneficial. Personally when called in consultation to a case, if I see the oxygen cylinder at the bedside I feel the prognosis to be extremely grave."

However, he did acknowledge,

"It does sometime seem to give transitory relief and to diminish cyanosis. It is harmless, its exhibition is very simple, and the process need not be at all disturbing to the patient" (17).

He recommended allowing the oxygen to flow gently under the nostrils or to be given by mask every other quarter of an hour. These recommendations were probably based on the reports of the presentations on pneumonia that had been a special consideration of the British Medical Association (BMA) council at its annual congress in August 1895 (18). The key speaker, Douglas Powell, recommended oxygen for its twofold actions: first, to keep the patient alive on a small respiratory surface and, second, to improve cardiac function. Powell commented that,

"The general practice of the London hospitals is only to use oxygen in desperate cases for the treatment of cyanosis, with the effect of maintaining life a little longer, but with no other good result. I would venture to urge its use also, and indeed, rather as a cardiac tonic, to anticipate, and if possible avert heart failure by helping cardiac nutrition. Oxygen also lessens that restlessness which is attendant upon defective aeration and hurried breathing. Its effect is to lower the pulse rate and to diminish the number of respirations" (18).

Of the 17 other presentations made at the congress, only Clifford Allbut, Regius Professor at Cambridge University (Cambridge, United Kingdom), mentioned oxygen and only then to consider that it was not of very much value.

In the fourth edition of his book (19), in 1901, Osler was able to justify his hesitation about oxygen by referring to the work of Lorrain Smith. He stated, "that it [oxygen] may under certain circumstances be positively harmful. He has shown that oxygen can be a serious irritant, actually producing inflammation in the lungs". Where had Osler learned this? In 1898, Lorrain Smith had presented his research at the annual meeting of the BMA in Edinburgh, Scotland. Lorrain Smith had exposed mice, guinea pigs and larks to various high concentrations of oxygen, and showed that they developed pulmonary damage. He warned that when administering oxygen the "transition from physiological to pathological was imperceptible" (20). Osler had attended this meeting, and Cushing stated that there was probably little he had missed in the way of excursions, receptions and scientific sessions, although in the same paragraph he also wrote, "he appears to have taken no part in the scientific sessions" (21). By this, I take it that Osler listened but did not take part in the discussions. Even if Osler had missed hearing Lorrain Smith's paper, it was reported both in the Lancet and the British Medical Journal before the full paper was published (20).

Osler retained his skepticism, and as late as the eighth edition in 1913 (22), he wrote for pneumonia, "The value of the administration of oxygen is doubtful". Yet this opinion was to be modified for the ninth edition in 1920 (23), of which Thomas MacRae was sole editor after Osler's death in 1919. MacRae wrote, "The guide to the use of oxygen is the effect of relieving distress and cyanosis". What made MacRae change the advice? Possibly it was founded on the new studies on oxygen and pneumonia that had been published, and in which our second McGill University professor had played a large part.

\section{The writings of Jonathan Meakins}

Jonathan Meakins was born in 1882, close to Osler's birthplace in Ontario. He went to McGill University and graduated in 1904. After postgraduate work in the United States and Britain with Sir Thomas Lewis and Sir James Mackenzie, he returned to McGill University in 1914 (24). Then, like many Canadians, he rallied to the flag and joined Number 3 Canadian General Hospital that was formed at McGill University. In May 1915, the McGill unit sailed for Europe in Her Majesty's Troopship Metagana, on which Major JC Meakins was appointed medical officer for the voyage (25).

The next chapter in our story had occurred on April 22nd, 1915. The Second Battle of Ypres had opened, and for the first time, the Germans successfully released chlorine gas, which blew down on the Allied Forces. The Canadian Brigade held fast, but many soldiers succumbed to the poison. Medical research into the toxic effects of this new weapon was instituted. Meakins, shortly after arrival in Britain, was transferred to the Medical Research Council Committee team, headed by JS Haldane, which was to study the effects of the poison gas. Haldane had seen his first gas casualties in April 1915, the victims of which had severe hypoxemia. Initially, he thought this was the result of methemoglobinemia, but tests showed it was simply hypoxemia. Chlorine had produced severe pulmonary damage with swollen and edematous alveolar walls. Meakins was a major player in the research, and was, in due course, in charge of Number 15 General Hospital at Taplow (Taplow, England), to which most of the Canadian gas sufferers were referred.

During the war years, Cushing recorded that Osler had heard of Meakins' arrival in January 1916, and mentioned him again on April 1st, 1916 in a letter to Billie Francis. On September 14th, 1918, Osler, most tellingly for our consideration, wrote to his old friend Francis Shepherd of McGill University, "I gave a little dinner on Thursday to Finley and Meakins who returns next week. F has been splendid. Meakins has done such good work - a great credit to McGill. He is a thoroughly scientific worker" (21).

The story continued with the world pandemic of the Spanish influenza that devastated the population far more than all the gas. In 1919, Stadie, from the Rockefeller Institute for Medical Research, published his observations on oxygenation of the blood in pneumonia and its relation to cyanosis (26). He had seen the severe cyanosis of the cases in which pneumonia had complicated influenza, and illustrated his paper with striking watercolours. Stadie, using the radial arterial puncture technique that had recently been described, investigated 33 patients with pneumonia. Francis Peabody had suggested that the cyanosis in pneumonia might be the result of methemoglobinemia (27), but Stadie found no evidence for this (26). He determined the oxygen content and unsaturation of the blood by the 
method of Van Slyke. In five healthy subjects, the mean unsaturation was 5\%. In 16 nonfatal cases of pneumonia, it was $13 \%$, and in 16 fatal cases $32 \%$. In those days unsaturation was reported. The depth of the cyanosis was related to the degree of unsaturation.

The fact that hypoxemia was a serious problem in pneumonia had been forecast by Haldane at the end of his classic account of the Pike's Peak expedition of 1911 (28). Haldane commented that cases of pneumonia at altitude in Cripple Creek were evacuated to the prairie level to recover. This led him to recommend the use of chambers enriched with oxygen for treating pneumonia. But the real benefit of demonstrating the value of oxygen for pneumonia lay with Meakins' postwar studies.

In 1919, Meakins, having returned to McGill University, applied his knowledge of the effects of gassing to the study of pneumonia. With Haldane and Priestley, he had already shown that abnormally shallow respiration produced 'anoxemia' using an ingenious technique that restricted the volume of air breathed by normal individuals while recording respiration (29). Meakins referred to their experience with irritable heart and suffocative gas poisoning, and other cases in which shallow respiration was found, in particular, pneumonia. He associated 'anoxemia' with a respiratory rate of 50 breaths/min. Therefore, Meakins performed expired air analysis in four cases of pneumonia and found that there was an increase in minute ventilation, a diminution of tidal air and increased dead space; all of which, he concluded, explained the cyanosis (30). Although shunting might have been expected through the consolidated lung, and that would also have produced anoxemia, he thought this was insufficient. He referred to the pathological observation of Gross (31) that demonstrated that pulmonary circulation is shut off in the consolidated lobe. Meakins, by now Christison Professor of Therapeutics at the University of Edinburgh, Scotland, turned to the effects of correcting the anoxemia. In a preliminary paper on the therapeutic value of oxygen, Meakins stated,

"The value of oxygen administration in pneumonia has been a subject of much controversy, and the present investigations were undertaken to determine whether oxygen adequately administered would increase the oxygen saturation of the arterial blood in this condition" (32)

He described the effect of oxygen in two cases of pneumonia, one of bronchitis and one in a normal person. Desaturation was reversed by oxygen treatment (32).

Later that year, Meakins published the full report (33). His opening sentence is worth repeating: "The grave effect of anoxaemia as evidenced by a slight degree of cyanosis has not been awarded the importance that it is due" (33). Meakins was familiar with Stadie's work, but felt that there may have been some variations in the estimation of the oxygen content using the Van Slyke method. Meakins chose to use what he considered the more accurate Haldane method (34). To treat the patients, Meakins had used the Haldane apparatus (35) first developed to administer oxygen for the treatment of gas poisoning. Meakins first tested the administration of oxygen on a healthy, young adult whose saturation was raised from $96 \%$ to $99 \%$ (33). He then studied a Canadian soldier who had been gassed in 1915, and who had been discharged unfit in 1916 with pronounced shortness of breath and other respiratory symptoms, including an inability to take a deep inspiration. With oxygen administration, the saturation rose from $96 \%$ to $99 \%$, and the soldier felt much better (33). Meakins provides a rationale for why the soldier felt better, although his saturation was already normal. Elsewhere, Meakins likened this situation to neurasthenia (36). In 10 cases of pneumonia, Meakins found a range of saturation from $80 \%$ to $92 \%$ (33). He found that this desaturation was associated with the serious cardiovascular and nervous phenomena observed in pneumonia. The administration of oxygen would be expected to relieve the anoxemia, and this was demonstrated in three cases, in which there was relief of symptoms as the saturation was restored (33). From then on, oxygen therapy became standard practice for pneumonia, and many trials were reported over the next decades by such luminaries as Barach and Woodwell (37) and Binger (38).

\section{CONCLUSIONS}

Physicians often use substances to treat disorders with no knowledge of what they are doing. This seems to be how oxygen was used initially. Priestley surmised that oxygen could be of benefit in disease, but harmful in health. Beddoes simply saw oxygen as a stimulant, and used it in consumption without obvious benefit. Osler seems to have had neither an understanding of the vital role of oxygen in the body's functioning, nor experience of the value of oxygen in the comfort of the sick. I surmise that he was simply aware of its use from anecdotal case reports. Osler learned of the toxicity of excess oxygen and, thus, was more concerned about its risks. This fits with his reputation as a therapeutic nihilist. Therefore, he, at best, tolerated the use of oxygen. Meakins had many advantages over Osler. First, he joined the team of the leading respiratory physiologist Haldane, which was studying the causes and effects of hypoxemia engendered by gas warfare. Second, the technological advances of arterial puncture and blood gas measurement meant that hypoxemia could be quantified. At first sight, Meakins's clinical trials look scientific because he could put measurements to his observations. But taking a critical look at the clinical part of the paper reveals that the value of oxygen to the patient's subjective well-being was simply described; hardly an improvement on the experiences of 19th century practice. The need for properly designed clinical trials as a true test of outcome lay in the future, and, in fact, have never happened. Oxygen became established as routine for pneumonia. Priestley's presumption that oxygen could be useful in medicine was confirmed. Osler died before Meakins's work was published. We can only speculate that Osler's aspiration to lifelong learning would have led him to accept the need for oxygen in pneumonia. Interestingly, Osler's uneasiness that the use of oxygen foretold a fatal prognosis was still echoed in 1944 by Coope in his chapter on pneumonia: "Some patients look upon the parson as they used to look on the oxygen cylinder - a last and desperate resort" (39).

ACKNOWLEDGEMENTS: The author thanks the staff of the JS MacLean Health Sciences Library, University of Manitoba; the Osler Library, McGill University; and the Wellcome Library, London, UK. The author also appreciated the advice and comments of the two referees. 


\section{REFERENCES}

1. Osler W. The Principles and Practice of Medicine. New York: Appleton \& Co, 1892.

2. Frank RG Jr. Harvey and the Oxford Physiologists. Berkeley: University of California Press, 1980.

3. Severinghaus JW. Priestley, the furious free thinker of the enlightenment, and Scheele, the taciturn apothecary of Uppsala. Acta Anaesthesiol Scand 2002;46:2-9.

4. Bean WH. Sir William Osler. Aphorisms from His Bedside, Teachings and Writings, \#112. Springfield: Charles C Thomas Company, 1968.

5. Priestley J. On Dephlogisticated Air. From Experiments and Observations on Different Kinds of Air. Volume II. London: 1775. Alembic Club Reprints Number 7. Edinburgh: Oliver and Boyd, 1923.

6. Porter R, ed. Doctor of Society: Thomas Beddoes and the Sick Trade in Late Enlightenment England. London: Routledge, 1992.

7. Beddoes T. A letter to Erasmus Darwin MD on a new method of treating Pulmonary Consumption and some other disease hitherto found incurable. 1793:50-4.

8. Beddoes T. Considerations on the Medicinal Use of Factitious Airs and the Manner of Obtaining Them. Bristol: Bulgin and Rosser, 1794.

9. Davy H. Researches Chemical and Philosophical: Chiefly Concerning Nitrous Oxide or Dephlogisticated Nitrous Air and Its Respiration. London: J Johnson, 1800.

10. Astrup P, Severinghaus JW. Blood gas transport and analysis. In: West J, ed. Respiratory Physiology. People and Ideas. New York: Oxford University Press, 1996.

11. Haldane JS. Effects of high atmospheric pressure. In: Respiration. New Haven: Yale University Press, 1922.

12. Kellogg JH. Oxygen enemata as a remedy for certain diseases of the liver and intestinal tract. JAMA 1888;XI:258-62.

13. Brunton LT, Prickett M. On the use of oxygen and strychnine in pneumonia. BMJ 1892;i:172-3.

14. Osler W. Summer session clinics. Numbers III and IV. Pneumonia. Stenographical report by James Crankshaw. 1882:14-36.

15. Osler W. The treatment of pneumonia. Medical News. 1887;March 19:324.

16. Golden RL. Osler's Legacy: The principles and practice of medicine. In: Barondess JA, Roland CG, eds. The Persisting Osler. Malabar: Krieger Publishing Co. 1994:47-60.

17. Osler W. The Principles and Practice of Medicine, 3rd edn. New York: Appleton \& Co, 1898.

18. Acute pneumonia. BMJ 1895;ii:1149-61.

19. Osler W. The Principles and Practice of Medicine, 4th edn. New York: Appleton \& Co, 1901.
20. Lorrain Smith J. The pathological effects due to increase of oxygen tension in the air breathed. J Physiol 1899;XXIV:19-35.

21. Cushing H. The Life of Sir William Osler. Oxford: Clarendon Press, 1925:476,617.

22. Osler W, with the assistance fo McRae T. The Principles and Practice of Medicine, 8th edn. New York: Appleton \& Co, 1913.

23. McRae T, Osler W. The Principles and Practice of Medicine, 9th edn. New York: Appleton \& Co, 1920.

24. Trail RR, ed. Munk's Roll, volume 5. London: Royal College of Physicians, 1968.

25. Fetherstonhaugh RC. No 3 Canadian General Hospital (McGill) 1914-1919. Montreal: The Gazette Printing Company, 1928.

26. Stadie WC. The oxygen of the arterial and venous blood in pneumonia and its relationship to cyanosis. J Exp Med 1919;XXX:215-40.

27. Peabody FW. The oxygen content of the blood in rabbits infected with pneumococcus. J Exp Med 1913;XVIII:1-17.

28. Douglas CG, Haldane JS, Henderson Y, Schneider EC. Physiological observations made on Pike's Peak, Colorado, with special references to adaptation to low barometric pressure. Phil Trans Roy Soc B 1913;CCIII:299.

29. Haldane JS, Meakins JC, Priestley JC. The effects of shallow breathing. J Physiol 1919;52:433-52.

30. Meakins J. Harmful effects of shallow breathing with special reference to pneumonia. Arch Intern Med 1920;XXV:1-5.

31. Gross L. Preliminary report of the reconstruction of the circulation of the liver, placenta and lung in health and disease. CMAJ $1919 ; 9: 632-4$

32. Meakins J. The therapeutic value of oxygen in pulmonary lesions. Preliminary Note. BMJ 1920;i:324-6.

33. Meakins J. Observations on the gases in human arterial blood in certain pathological pulmonary conditions and their treatment with oxygen. J Pathol 1920;XXIV:79-90.

34. Haldane JS. The ferricyanate method of determining the oxygen capacity of blood. J Physiol 1921;XXVIII:34-42.

35. Haldane JS. A lecture on the symptoms, causes and prevention of anoxaemia and the value of oxygen in its treatment. BMJ 1919;ii:65-71.

36. Meakins JC, Davies HW. Respiratory Function in Disease. Edinburgh: Oliver and Boyd, 1925.

37. Barach AL, Woodwell AB. Studies on oxygen therapy. II: In pneumonia and its complications. Arch Int Med 1926;XXXVII:186-93.

38. Binger CAL. Anoxemia in pneumonia and its relief by oxygen inhalation. J Clin Invest 1928;VI:203-19.

39. Coope R. Diseases of the Chest. Edinburgh: E \& S Livingstone, 1948. 


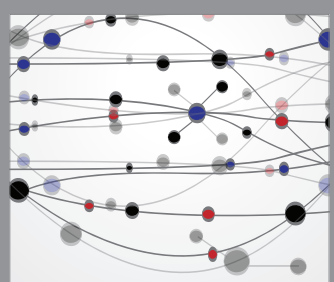

The Scientific World Journal
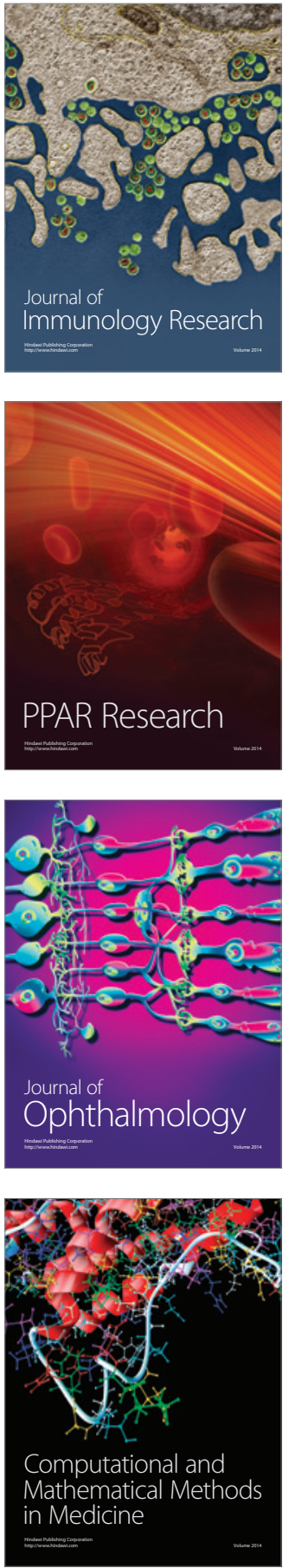

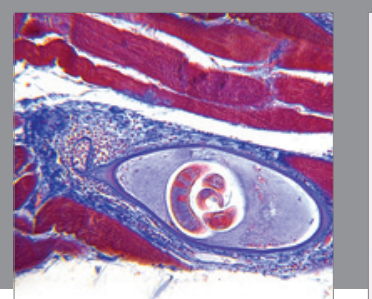

Gastroenterology Research and Practice

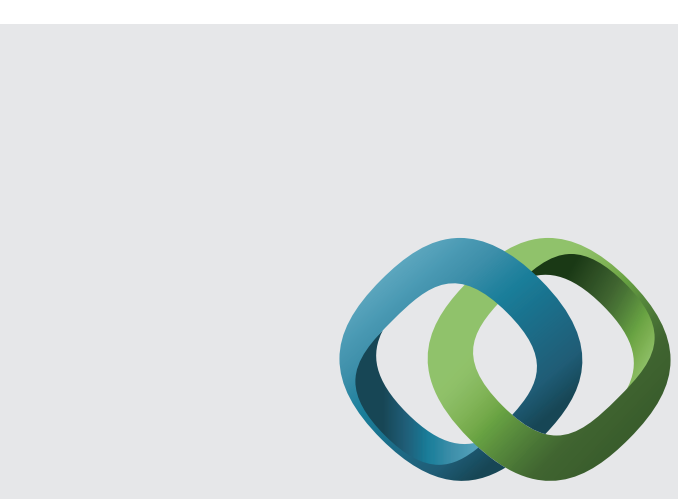

\section{Hindawi}

Submit your manuscripts at

http://www.hindawi.com
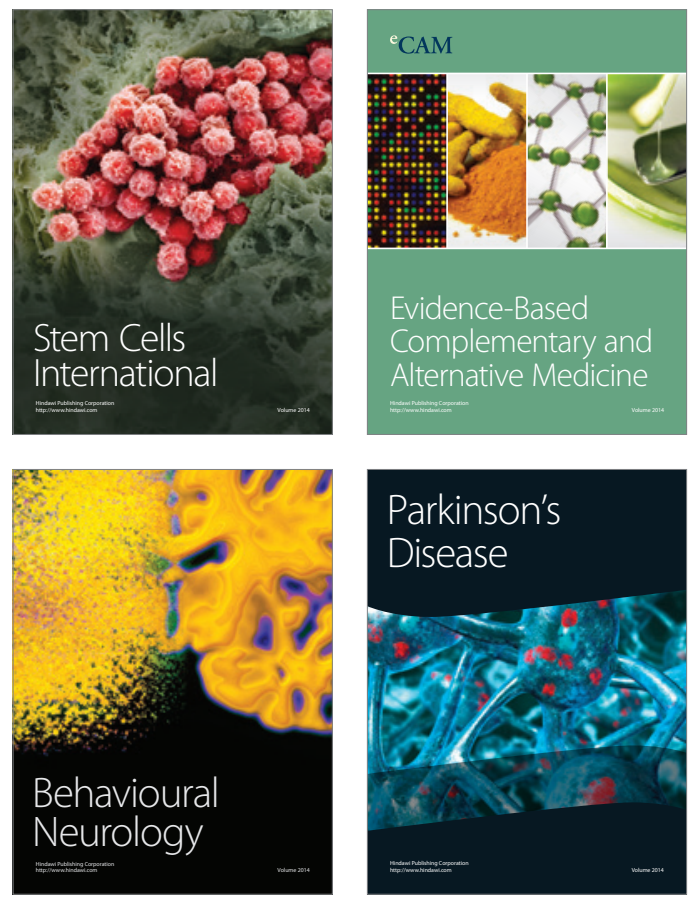
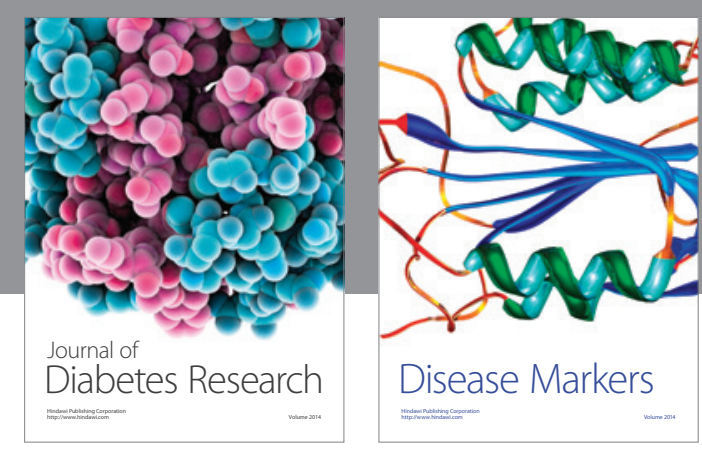

Disease Markers
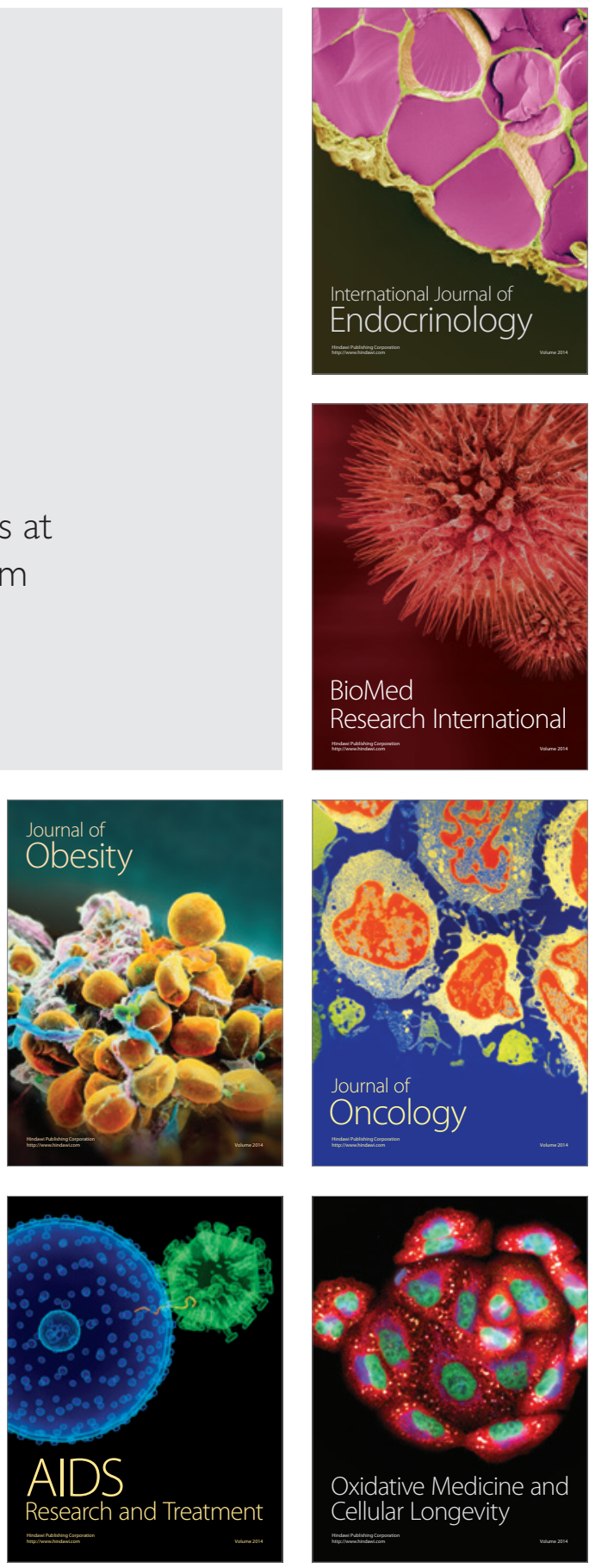